\section{Population Density and Nitrogen Fertility Effects on Tomato Growth and Yield}

\author{
Elizabeth A. Wahle ${ }^{1}$ and John B. Masiunas ${ }^{2}$ \\ Department of Natural Resources and Environmental Sciences, University of \\ Illinois, 1201 West Gregory Drive, Urbana, IL 61801
}

Additional index words. hydroponics, ${ }^{15} \mathrm{~N}$, fertility, competition, Lycopersicon esculentum, Lycopersicon lycopersicum

\begin{abstract}
Greenhouse hydroponics and field experiments were conducted to determine how nitrogen $(\mathrm{N})$ fertilizer treatments affect tomato (Lycopersicon esculentum Mill.) growth, yield, and partitioning of $\mathrm{N}$ in an effort to develop more sustainable fertilization strategies. In a hydroponics study, after 4 weeks in nitrate treatments, shoot dry weight was five times greater at 10.0 than at $0.2 \mathrm{~mm}$ nitrate. An exponential growth model was strongly correlated with tomato root growth at all but $0.2 \mathrm{~mm}$ nitrate and shoot growth in $10 \mathrm{~mm}$ nitrate. Root dry weight was only $15 \%$ of shoot biomass. In field studies with different population densities and $\mathrm{N}$ rates, height in the 4.2 plants $/ \mathrm{m}^{2}$ was similar, but shoot weight was less than in the 3.2 plants $/ \mathrm{m}^{2}$. At 12 weeks after planting, shoot fresh weight averaged 3.59 and $2.67 \mathrm{~kg} /$ plant in treatments with 3.2 and 4.2 plants $/ \mathrm{m}^{2}$, respectively. In 1998 , final tomato yield did not respond to $\mathrm{N}$ rate. In 1999, there was a substantial increase in fruit yield when plants were fertilized with $168 \mathrm{~kg} \cdot \mathrm{ha}^{-1} \mathrm{~N}$ but little change in yield with additional $\mathbf{N}$. Nitrogen content of the leaves and the portion of $\mathbf{N}$ from applied fertilizer decreased as the plants grew, and as $\mathbf{N}$ was remobilized for fruit production. Both studies indicate that decreasing $\mathbf{N}$ as a way to reduce $\mathbf{N}$ loss to the environment would also reduce tomato growth.
\end{abstract}

Tomato is one of the most valuable vegetable crops for both fresh market and processing in the United States [U.S. Dept. of Agriculture (USDA), 2001]. Current tomato production systems require high levels of $\mathrm{N}$ and irrigation for optimum growth. These systems can pollute surface and groundwater. High levels of $\mathrm{N}$ can also encourage pest problems, such as nightshade (Solanum sp.) weeds (Gonzalez Ponce and Salas, 1999). A better understanding of tomato utilization of $\mathrm{N}$ fertilizer is necessary to develop more sustainable production practices.

An adequate $\mathrm{N}$ supply is critical for tomato production. Tomato has continuous $\mathrm{N}$ accumulation throughout its growth and development. The percentage of total $\mathrm{N}$ in tomato leaves drops steadily from the seedling stage to the start of fruit development. At the seedling stage, $\approx 80 \%$ of the total $\mathrm{N}$ in the plant can be found in the leaves. Afterwards there is a shift in $\mathrm{N}$ accumulation from the leaves to the developing fruit. At harvest, $\approx 24 \%$ of the total $\mathrm{N}$ is in the leaves and $\approx 69 \%$ is in the fruit (Wilcox, 1993).

Received for publication 14 Jan. 2002. Accepted for publication 18 July 2002. This paper is a portion of a thesis submitted by E.A.W. in partial fulfillment of the requirements for $\mathrm{PhD}$ degree. The research was supported by funds from Hatch project \#65-0334 of the Univ. of Illinois Agricultural Experiment Station. We thank John Swiader and Richard Mulvaney for the use of their laboratories to conduct the nitrogen analysis.

${ }^{1}$ Former Graduate Research Assistant, currently Extension Educator.

${ }^{2}$ Associate Professor; to whom reprint requests should be addressed. it is necessary to study how tomato utilizes $\mathrm{N}$ (Sanchez and Doerge, 1999). The objective of this study was to determine how population density and fertility treatments affect tomato growth, yield, and partitioning of $\mathrm{N}$.

\section{Materials and Methods}

Greenhouse hydroponics study. Hydroponic research was conducted to determine the effect of nitrate level on tomato dry weight accumulation. The experiments were conducted in Oct. through Dec. 1996, and Mar. through May 1999. The hydroponic system consisted of plastic vessels $\approx 7.5 \mathrm{~L}$ in volume that held six tomato plants, evenly spaced around the circumference of the lid (Wahle, 2001). 'Rutgers' tomato (Totally Tomatoes, Augusta, Ga.) plants were acclimated to the hydroponics system by introducing them to a transplanting solution at the two-leaf stage. The transplanting solution was a mixture of a $1 \mathrm{~mm}$ nitrate- $\mathrm{N}$ solution with $\mathrm{P}, \mathrm{K}, \mathrm{S}, \mathrm{Ca}, \mathrm{Mg}$, and a half-strength micronutrient solution, based on a modified Hoagland's solution (Resh, 1995; Table 1). Uniform, vigorously growing seedlings were inserted into the plant holes in the lid of the hydroponic container. The solution level and $\mathrm{pH}$ were monitored daily in the individual containers. Deionized water was added to maintain the original solution level and the $\mathrm{pH}$ was maintained within the range of 5.8 to 6.4 using hydrochloric acid $(0.5 \mathrm{~N})$ or sodium hydroxide $(1 \mathrm{~N})$.

After 1 week, plants were introduced into four treatment solutions containing $0.2,1.0$, 5.0 , or $10.0 \mathrm{~mm}$ nitrate-N (Table 1). In fertile soils, nitrate- $\mathrm{N}$ is most commonly between 2 and $10 \mathrm{~mm}$ (Asher, 1978). Because of the need for counter ions with the nitrate, concentrations of potassium, calcium, magnesium, sulfur, and chlorine varied, but were all sufficient and within the normal range for plants (Table 1). Each nitrate treatment contained the full rate of micronutrients in Hoagland's solution. The treatments were adjusted to $\mathrm{pH} 6.0$ with sulfuric acid $(0.5 \mathrm{~N})$ or potassium hydroxide $(1.0 \mathrm{~N})$ before plants were introduced into the solutions. The solution levels and $\mathrm{pH}$ range of 5.8 to 6.4 were maintained as described above for the transplant solution.

Because nitrate absorbs UV radiation, spectrophotometric analysis provides a quick and easy method to monitor nitrate concentrations (Mulvaney, 1996; Norman and Stucki, 1981; Norman et al., 1985). Solution samples were monitored daily for nitrate concentration using an ultraviolet spectrophotometer. Individual container solutions were recharged using potassium nitrate $\left(\mathrm{KNO}_{3}\right)$ when nitrate levels dropped to half their original concentration. All containers were drained and the solutions were replaced every $7 \mathrm{~d}$.

In 1996, plants were harvested at 0,2 , or 4 weeks after initiation of the nitrate treatments. In 1999, plants were harvested at 1, 3, or 4 weeks after initiation of the nitrate treatments. The experiment was terminated at 4 weeks after initiation of $\mathrm{N}$ treatments when tomato started to set fruit. The roots and shoots were separated and dried at $45^{\circ} \mathrm{C}$ until a constant 
Table 1. The nutrient solutions used for the greenhouse hydroponic study. The solutions were based on the modified Hoagland's solution used by Crotser and Masiunas (1998).

\begin{tabular}{|c|c|c|c|c|c|c|c|c|c|c|c|c|c|}
\hline \multirow{2}{*}{$\begin{array}{l}\text { Nitrate } \\
\text { treatment }(\mathrm{mm})\end{array}$} & \multicolumn{13}{|c|}{ Nutrient concentration } \\
\hline & $\mathrm{Na}$ & $\mathrm{P}$ & $\mathrm{K}$ & $\mathrm{Ca}$ & $\mathrm{Mg}$ & $\mathrm{S}$ & $\mathrm{Cl}$ & B & Mo & $\mathrm{Cu}$ & $\mathrm{Mn}$ & $\mathrm{Zn}$ & $\mathrm{Fe}$ \\
\hline Q & & & & & & 7 & $\mathrm{ng} \cdot \mathrm{L}$ & & & & & & 50 \\
\hline 5.0 & 70 & 16 & $\begin{array}{l}180 \\
159\end{array}$ & $\begin{array}{l}134 \\
134\end{array}$ & 36 & $\begin{array}{l}4 / \\
84\end{array}$ & $\begin{array}{r}60 \\
105\end{array}$ & $\begin{array}{l}0.50 \\
0.50\end{array}$ & $\begin{array}{l}0.51 \\
0.51\end{array}$ & $\begin{array}{l}0.51 \\
0.51\end{array}$ & 0.497 & 0.10 & 5.0 \\
\hline 1.0 & 14 & 16 & 159 & 110 & 36 & 104 & 159 & 0.50 & 0.51 & 0.51 & 0.497 & 0.10 & 5.0 \\
\hline 0.2 & 2.8 & 16 & 159 & 110 & 36 & 104 & 187 & 0.50 & 0.51 & 0.51 & 0.497 & 0.10 & 5.0 \\
\hline
\end{tabular}

${ }^{\mathrm{z}} \mathrm{All}$ nitrogen was in the form of nitrate.

weight was obtained. The data were analyzed using the general linear model procedure of SAS (SAS, 1998). If the $\mathrm{N}$ treatment was significant, means were separated using Fisher's protected least significant difference (LSD) test. In 1999, when plant dry weight was determined at 1,3 , and 4 , linear, quadratic, and exponential equations:

$$
\begin{aligned}
& \text { plant dry weight }=a+b x \\
& \text { plant dry weight }=a+b x+c^{2} \\
& \text { plant dry weight }=a\left(e^{b(x)}\right)
\end{aligned}
$$

were fitted to the data. The " $x$ " is days after initiation of $\mathrm{N}$ treatments and the " $\mathrm{a}$ " parameter represents the y-intercept term and serves as an estimate of the plant weight at initiation of the experiment. The "b" parameter represents the slope or growth rate in the linear regression and for the exponential equation " $\mathrm{b}$ " is the relative growth rate (McGiffen and Masiunas, 1992a).

Field study. The objective was to determine how $\mathrm{N}$ fertilizer and population density interact to influence tomato growth, yield, and $\mathrm{N}$ partitioning. The study was conducted in 1998 and 1999 at the Univ. of Illinois, Cruse Tract Vegetable Research Farm in Champaign. The soil type was a Flanagan silt-loam (fine, montmorillonitic, mesic Aquic Argiudoll; $\mathrm{pH}$ 6.2 to 6.3 and organic matter $2.8 \%$ to $2.9 \%$ ). The study was a factorial in a randomized complete-block design with five replications. The factors were tomato plant density and $\mathrm{N}$ treatment. Plots were $1.5 \times 1.2 \mathrm{~m}\left(1.9 \mathrm{~m}^{2}\right)$ and were separated on all sides by a $1.5-\mathrm{m}$ bare ground border.

'Wheeler' rye (Secale cereale L.) was planted in mid-October in the experimental area to ensure a uniform previous crop and to immobilize some of the residual soil $\mathrm{N}$. In the spring, the rye was killed with an application of $1.1 \mathrm{~kg} \cdot \mathrm{ha}^{-1}$ glyphosate [ $\mathrm{N}$-(phosphonomethyl) glycine] and mowed $\approx 1$ week later. After mowing the entire experimental area was treated with triple superphosphate (0-19-0), and potash (0-0-50), at an equivalent rate of $100 \mathrm{~kg} \cdot \mathrm{ha}^{-1} \mathrm{P}$ and $440 \mathrm{~kg} \cdot \mathrm{ha}^{-1} \mathrm{~K}$, respectively. Trifluralin, [2-6-dinitro- $N, N$-dipropyl-4-(trifluoromethyl) benenanine], was applied at $0.8 \mathrm{~kg} \cdot \mathrm{ha}^{-1}$ to control grass and some broadleaf weeds. The entire field was then disked to incorporate the rye, trifluralin, triple superphosphate, and potash.

The four $\mathrm{N}$ treatments consisted of a bare ground control with no $\mathrm{N}$ fertilizer; $0 \mathrm{~N}$ plus $22.4 \mathrm{mg} \cdot \mathrm{ha}^{-1}$ sawdust applied to immobilize available soil $\mathrm{N} ; 168 \mathrm{~kg} \cdot \mathrm{ha}^{-1} \mathrm{~N}$; and $336 \mathrm{~kg} \cdot \mathrm{ha}^{-1}$ $\mathrm{N}$ in the form of ammonium nitrate $\left(\mathrm{NH}_{4} \mathrm{NO}_{3}\right)$. The sawdust, consisting of mixed hardwoods and softwoods, moist from rainfall but still very friable, was applied by hand on 21 May 1998 and 20 May 1999. To allow N from the fertilizer to be separated from residual $\mathrm{N}$ in the soil, $\mathrm{NH}_{4} \mathrm{NO}_{3}$ enriched with 5 atom percent ${ }^{15} \mathrm{~N}$ was used (Isotech, Miamisburg, Ohio). On 28 May 1998, and 20 May 1999, crystalline $\mathrm{NH}_{4} \mathrm{NO}_{3}$ was dissolved in water and applied to appropriate plots using a handheld $\mathrm{CO}_{2}$ sprayer equipped with $8003 \mathrm{VS}$ flat fan spray nozzles (TeeJet-Spraying System Co., Wheaton, Ill.) at $30 \mathrm{kPa}$. The sawdust and $\mathrm{N}$ treatments were incorporated immediately following application using a tractor-mounted rotatiller.

'Mountain Supreme' tomato plants were grown in the greenhouse as described in McGiffen et al. (1992b), and after 6 weeks transplanted into the plots. Two tomato populations of 3.2 and 4.2 plants $/ \mathrm{m}^{2}$ were planted on 1 June 1998 and 20 May 1999. The 4.2 plants $/ \mathrm{m}^{2}$ treatment consisted of two rows with four plants per row, with $45.7 \mathrm{~cm}$ between rows and 30.5 $\mathrm{cm}$ between plants within the rows. The 3.2 plants $/ \mathrm{m}^{2}$ treatment consisted of two rows with three plants per row, with $45.7 \mathrm{~cm}$ between rows and $45.7 \mathrm{~cm}$ between plants within the rows. Densities for commercial fresh market tomato production are $150 \mathrm{~cm}$ or more between rows and 45 to $76 \mathrm{~cm}$ between plants within the row giving populations of 7,180 to 14,400 plants/ha (UICES, 2001). Our objective in using high population density in this study was to understand the effect of intraspecific competition among tomato plants on crop growth, yield, and $\mathrm{N}$ utilization. Also, previous studies with soybeans have indicated that a square planting scheme that has equal distance between and within rows maximizes competitiveness and yield (Moore, 1991).

No starter fertilizer was applied during transplanting. Weeds were removed by rotatilling, cultivation, and hand-hoeing. In addition, $0.31 \mathrm{~kg} \cdot \mathrm{ha}^{-1}$ sethoxydim, 2-[1(ethoxyimino)butyl-5-[2-(ethylthio)propyl]3 hydroxy-2 cyclohexen-1-one, a selective postemergence grass-active herbicide was applied on 19 June 1998. Insecticides registered for use on tomato were applied twice in 1998 and three times in 1999 to control insect feeding. Carbaryl (1-naphthyl $N$-methylcarbamate) was applied at $1.12 \mathrm{~kg} \cdot \mathrm{ha}^{-1}$ a.i. on 25 June 1998, and 17 June 1999. Permethrin, (3-phenoxyphenyl)methyl ( \pm )cis-trans 3(2,2-dichloroethenyl)-2,2-dimethylcyclopropanecarboxylate, was applied at $0.22 \mathrm{~kg} \cdot \mathrm{ha}^{-1}$ a.i. on 24 July 1998, and 11 July and 3 Aug. 1999. Tomatoes were irrigated with $2.5 \mathrm{~cm}$ of water on 20 July and 7 Sept. 1998, and 11 June and 7 July 1999.

Plant height was measured at 3, 5, and 7 weeks after planting (WAP). Tomato plant samples were taken at: flowering (8 WAP); immature-green fruit (10 WAP); mature-green fruit (12 WAP); and full-ripe fruit (15 WAP) stages. Only the most recent, fully mature leaves were sampled at the flowering and immature-green fruit stages. Individual plant fresh weight and both lower and upper leaf and stem samples were collected at the mature-green and full-ripe fruit stages. The tissue samples were air-dried prior to $\mathrm{N}$ analysis.

Nitrogen analysis. The air-dried plant samples were ground to a powder using a Wiley mill equipped with a 60-mesh screen. The Kjeldahl digestion followed the procedures outlined in Stevens et al. (2000). A sample weighing $0.050 \pm 0.005 \mathrm{~g}$ was used in the Kjeldahl digestion. This provided enough tissue for analysis while avoiding excessive foaming. After the Kjeldahl digestion, samples were analyzed for total $\mathrm{N}$ using Mason-jar diffusion methodology (Stevens et al., 2000).

The analysis of ${ }^{15} \mathrm{~N}$ was started by adding $1 \mathrm{M} \mathrm{H}_{2} \mathrm{SO}_{4}$ to the $\mathrm{H}_{3} \mathrm{BO}_{3}$ solution $\left(0.05 \mathrm{~L}^{-\mathrm{g}^{-1}}\right.$ of $\mathrm{N}$ ) and heating it to dryness on a hot plate. Samples were processed according to the procedure of Stevens et al. (2000). Samples were redissolved in deionized water on microplates, dried, and ${ }^{15} \mathrm{~N}$ content determined using a mass spectrometer(Stevens etal., 2000). The proportion of ${ }^{15} \mathrm{~N}$ in the sample (PL) under analysis was calculated as:

$$
\mathrm{PL}=(\mathrm{AL}-\mathrm{AU}) /(\mathrm{AM}-\mathrm{AU})
$$

where $\mathrm{AL}$ is the atom $\%{ }^{15} \mathrm{~N}$ in the sample, $\mathrm{AU}$ is the natural abundance of atom $\%{ }^{15} \mathrm{~N}$, and $\mathrm{AM}$ is the atom $\%{ }^{15} \mathrm{~N}$ of the fertilizer applied. The relative abundance of ${ }^{15} \mathrm{~N}$ in unenriched nitrogen (AU), 0.366 atom \%, was used for calculations (Hauck et al., 1994).

The data were analyzed using the general linear model procedure of SAS (SAS Institute, Cary, N.C.). If population density was significant, then the means were separated using a $t$ test. Secondly, data for the 0,168 , and $336 \mathrm{~kg} \cdot \mathrm{ha}^{-1} \mathrm{~N}$ treatments were analyzed using regression analysis to determine its fit to linear, quadratic, or exponential equations. The appropriate equation was determined based on level of significance and coefficient of determination.

\section{Results and Discussion}

Greenhouse hydroponics study. After 4 weeks in the nitrate treatments (WINT), tomato shoot dry weight responded to nitrate rate (Fig. 1). Tomato plant weight was greatest when grown in a 5 or $10 \mathrm{~mm}$ nitrate solution. The nitrate concentrations that produced the most tomato shoot growth are toward the high end of the nitrate levels most commonly found in field soils and this supports the findings of other researchers that tomato growth and yields increase with increasing $\mathrm{N}$ rates (Hoyt et al., 1994; Mortley et al., 1991; Wyatt et al., 2001).

The response of root dry weight to nitrate differed between the 2 years. In 1996 after 4 WINT, root dry weight did not respond to $\mathrm{N}$ rate. In 1999, N rate significantly affected root growth. There was a significant linear increase 
in root weight with increasing $\mathrm{N}$ rate (Fig. 1). This suggests that none of the nitrate rates in the present study optimized root growth in the hydroponics solution at 4 WINT. Even though the study was conducted in the greenhouse with supplemental lighting, environmental conditions likely varied between the 2 years. The 1996 experiment was conducted during late November and December when the weather was cloudy and the lower temperature set point was difficult to maintain while the 1999 study was conducted in late April and May when the weather was sunny and the upper set point temperature was difficult to maintain. The lower temperatures and irradiance during 1996 than 1999 likely confounded the effect of nitrate treatment.

As was expected, root dry weight was consistently less than shoot dry weight. Resh (1995) reported that roots often account for a small portion of the biomass when plants are grown in hydroponics. Hydroponics culture allowed the tomato roots easy access to water and nutrients. Also, the tomato root system did not have to anchor or support the plants, so it was very branched and composed of fine feeder roots without much weight.

An exponential equation predicted root dry weight accumulation at all nitrate concentrations except $0.2 \mathrm{~mm}$ (Fig. 2). At $0.2 \mathrm{~mm}$ root dry weight was predicted by a linear equation. There was no plateauing of root dry weight accumulation. The relative growth rate for the roots depended on nitrate concentration, ranging from 0.0738 to $0.116 /$ day. At $10 \mathrm{~mm}$ nitrate, the relative growth rate was 0.133 and $0.116 /$ day for the shoot and roots, respectively. The lower relative growth rate for the roots indicates that the tomato plants were maximizing shoot growth at the expense of root growth.

The hydroponics study revealed that tomato growth can be limited when grown in solutions with $<5 \mathrm{~mm}$ of $\mathrm{N}$. Based on this and companion studies (Wahle and Masiunas, 2003a, 2003 b), tomato shoot weight is reduced at low $\mathrm{N}$ rates, suggesting that reducing $\mathrm{N}$ fertilizer applications would not be a strategy to use for improving the sustainability of tomato cropping systems. Fertilization strategies should aim to optimize tomato growth, so tomatoes will be competitive and produce optimum yields.

Field study. Tomato height was unaffected by population density (data not shown). 'Mountain Supreme' is a determinant type of tomato and may not respond to increased intraspecific competition by elongating. Moreover, the tomato plants may not have been large enough by 7 WAP for intraspecific competitive to have occurred. How tomato responds to competition is important because the plant which overtops others has a competitive advantage (Gonzalez Ponce et al., 1996; McGiffen et al., 1992b).

Plants grown at a greater population density (4.2 plants $/ \mathrm{m}^{2}$ ) had less weight and lower yield per plant. At 15 WAP, shoot fresh weight and fruit yield in plots with 3.2 plants $/ \mathrm{m}^{2}$ averaged 5.29 and $4.24 \mathrm{~kg} /$ plant, respectively while in plots with 4.2 plants $/ \mathrm{m}^{2}$ they averaged 4.17 and $3.31 \mathrm{~kg} /$ plant, respectively. At 15 WAP, the lower shoot fresh weight and fruit yields can probably be attributed to greater intraspecific

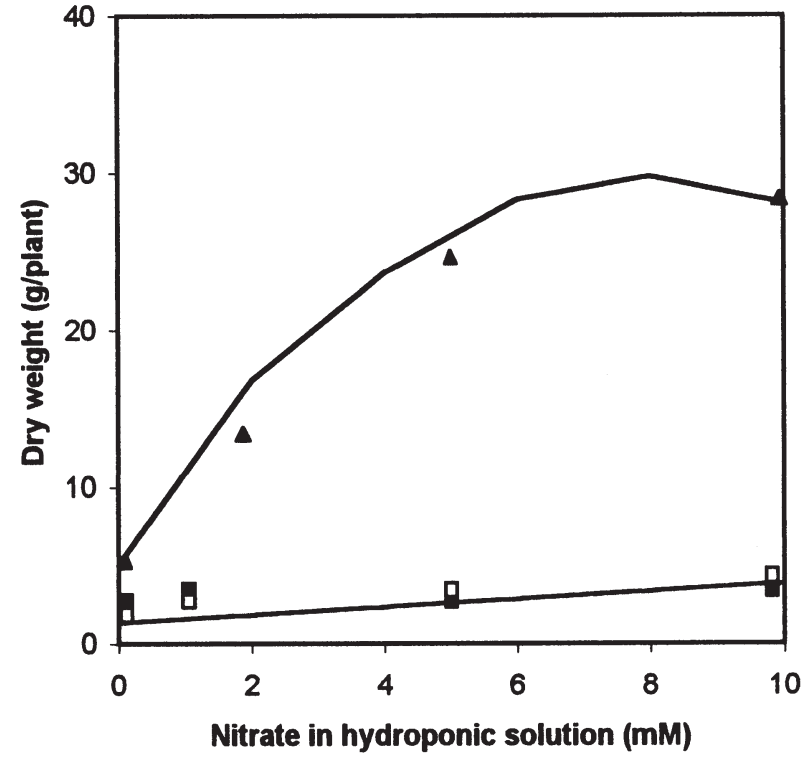

Fig. 1. 'Rutgers' tomato shoot dry weight averaged over both years and root dry weight after 4 weeks in hydroponic solutions. Root dry mass in 1996 ( ) was not affected by nitrate concentration (x). The equations were: root dry weight $(1999)=1.32+0.253 \mathrm{x}\left(r^{2}=0.77\right)$ and shoot dry weight (averaged over 1996 and 1999$)=5.09+6.22 \mathrm{x}-0.392 \mathrm{x}^{2}\left(R^{2}=0.93\right)$. The lines are the equations and the symbols are the actual data points.
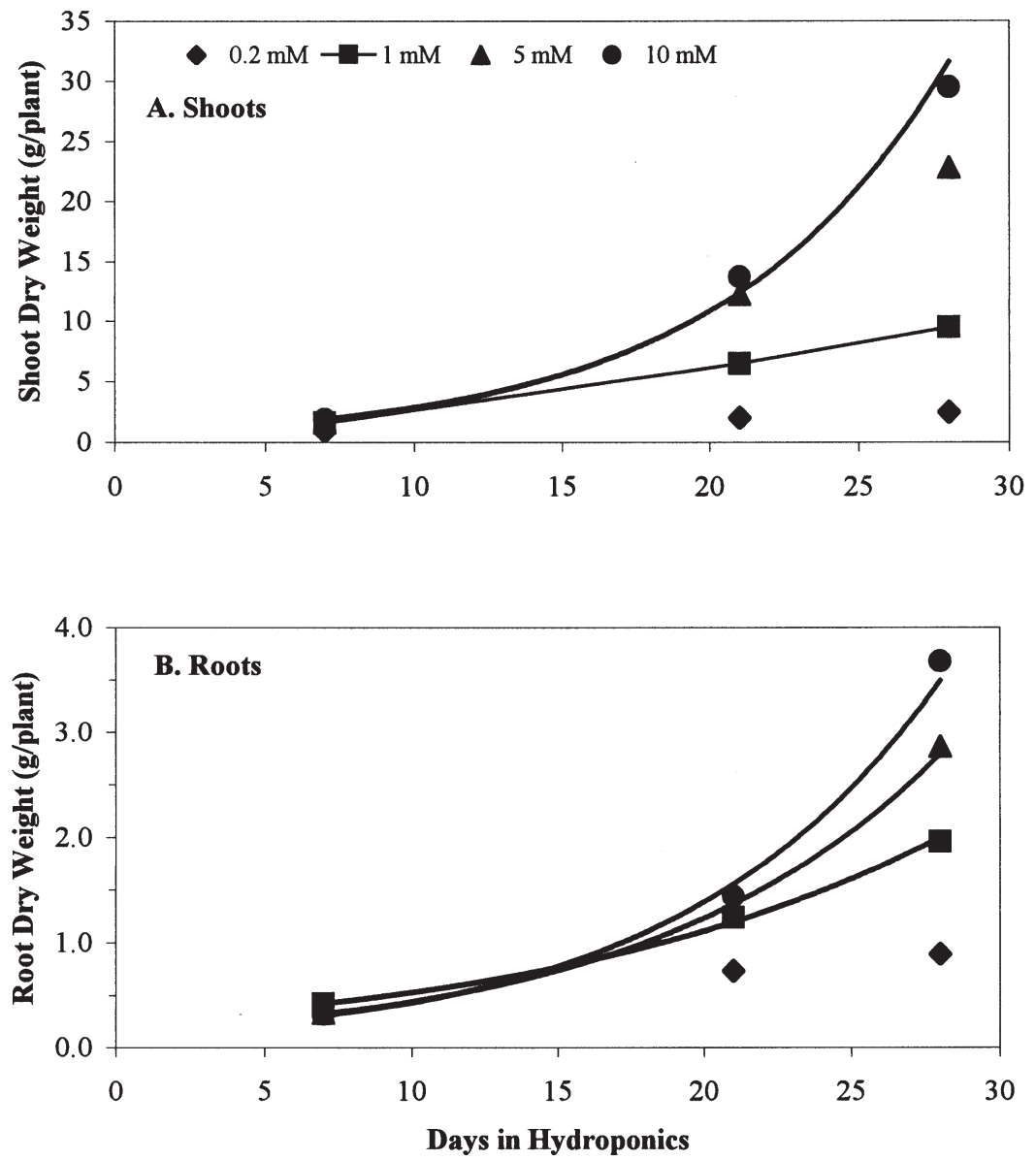

Fig. 2. The increase in (A) tomato shoot and (B) root dry weight as a function of days (x) growing in four different nitrate solutions. All coefficients of determination were $>0.90$. The equations for tomato shoots growing in 1 and $10 \mathrm{~mm}$ nitrate were: shoot weight $=0.582+0.00969 \mathrm{x}^{2}$; and shoot weight $=0.748^{[\mathrm{e} 0.133(\mathrm{x})]}$, respectively. The effect of days on shoot dry weight for plants grown in 0.2 and $5 \mathrm{~mm}$, although significant, could not be predicted with a linear, quadratic, or hyperbolic model. The equations for tomato roots growing in $0.2,1,5$, and $10 \mathrm{~mm}$ nitrate were: root weight $=0.0744$ $+0.0223 \mathrm{x}$; root weight $=0.253^{[\mathrm{e} 0.0738(\mathrm{x})]} ;$ root weight $=0.159^{[\mathrm{e} 0.102(\mathrm{x})]}$; and root weight $=0.136^{[\mathrm{e} 0.116(\mathrm{x})]}$, respectively. 
competition at the higher population density. Smith et al. (1992) also found that increasing tomato density reduced yield/plant. There were no differences between densities when shoot fresh weight and fruit yields of tomato were considered on an area basis. The shoot weight/ha averaged 30.4 and $92.2 \mathrm{Mg} \cdot \mathrm{ha}^{-1}$ at 12 and 15 WAP, respectively. This indicates that at the population range used in the present study, individual tomato plant weight changes so tomato produces a constant weight per unit area.

In a greenhouse replacement series experiment, Perez and Masiunas (1990) found that intraspecific competition resulted in smaller tomato plants than did competition with eastern black nightshade (Solanum ptycanthum Dun.). Our results also suggest that increasing the high density of tomatoes we used will not be an effective strategy either to maximize crop growth, improve sustainablity, or to increase competitiveness with weeds because the higher densities will adversely impact growth per tomato plant. Since there is a cost associated with using additional tomato plants, using high population levels would not be economical if competitiveness or yield are not increased.

Tomato height, growth rate, fresh weight, and yield increased with $\mathrm{N}$ fertilizer rate (Table 2). At $3 \mathrm{WAP}$, plants in plots with either no $\mathrm{N}$ or with sawdust were shorter than plants in plots with $\mathrm{N}$ fertilizer (Fig. 3A). We expected the sawdust to immobilize residual soil $\mathrm{N}$, resulting in the least amount of tomato growth, but at 3 WAP, there were no differences in height between plants in the sawdust and no fertilizer treatments. This was probably because tomato was recently established and the plants were able to use residual $\mathrm{N}$ from fertilization in the greenhouse for initial growth in the field. Other researchers have also found that $\mathrm{N}$ fertilization of greenhouse tomato transplants affects subsequent growth in the field (Garton and Widders, 1990; Liptay and Nicholls, 1993; Melton and Dufault, 1991).

At 5 and 7 WAP, plants in the sawdust treatment were shorter than those in any other treatment, including the no fertilizer (Fig. 3A). For example, at 5 WAP the plants in the sawdust treatment were $43 \mathrm{~cm}$ in height while those in the $168 \mathrm{~kg} \cdot \mathrm{ha}^{-1} \mathrm{~N}$ treatment were $63 \mathrm{~cm}$. This was probably because the sawdust promoted immobilization of N. Later in the season, unfertilized plants and plants receiving sawdust had similar weight (Table 3 ) and $\mathrm{N}$ in their tissues (Table 4). In the fertile soil (Wahle, 2001) in the present study, sawdust applied may have been inadequate to immobilize $\mathrm{N}$ throughout the entire season.

The effect of $\mathrm{N}$ treatment on shoot weight and fruit yield differed from its effect on height (Table 2). The optimum $\mathrm{N}$ treatment for production of shoot weight and fruit yield varied between years and measurement times, which means that our research cannot provide an overall $\mathrm{N}$ recommendation to maximize tomato growth and yield. Shoot fresh weight and yield responded to increased $\mathrm{N}$ rates (Table 3, Fig. 3B). Yields were greatest with $336 \mathrm{~kg} \cdot \mathrm{ha}^{-1}$ $\mathrm{N}$, and lowest with sawdust added (Fig. 3B). At 15 WAP, fresh weight per plant was smaller shoots reported by Qasem (1992).

The N content of tomato plants decreased from 8 to 15 WAP (Table 4). This was probably because $\mathrm{N}$ was being remobilized from the leaves and stem to the developing tomato fruit, and due to dilution caused by plant growth (Gonzalez Pounce and Salas, 1999; Smith et al., 1992). Also the amount of $\mathrm{N}$ available in the soil from the preplant fertilizer application was decreasing. For example, at 8 WAP, $49 \%$ of the $\mathrm{N}$ in the upper leaves was from fertilizer, but at 15 WAP only $10 \%$ of the $\mathrm{N}$ was from fertilizer and the remainder was from mineralized N. Gonzalez Ponce and Salas (1999) also reported high $\mathrm{N}$ concentrations in tomato tissue during initial growth stages and a decline later in the season.

The only effects of $\mathrm{N}$ treatment were on the $\mathrm{N}$ concentration of the upper leaves and on the percentage of $\mathrm{N}$ from fertilizer in the upper leaves and stem. At 8 WAP, population and $\mathrm{N}$ treatment interacted to determine the $\mathrm{N}$ content of the upper leaves (Table 4). With 3.2 plants/ $\mathrm{m}^{2}, \mathrm{~N}$ concentration of the upper leaves was greatest with $336 \mathrm{~kg} \cdot \mathrm{ha}^{-1} \mathrm{~N}$. With 4.2 plants $/ \mathrm{m}^{2}$, the only difference in $\mathrm{N}$ concentration in the upper leaves was between plants without added $\mathrm{N}$ and those in the $336 \mathrm{~kg} \cdot \mathrm{ha}^{-1} \mathrm{~N}$ treatment. At 12 WAP, the $\mathrm{N}$ content was higher in plants in the sawdust and $0 \mathrm{~N}$ plots than in plots treated with fertilizer. This result is unexpected and only occurred for the upper leaves at 12 WAP. It might indicate a later shift to reproductive growth or less dilution for the smaller plants in the $0 \mathrm{~N}$ and sawdust treatments causing them to maintain higher $\mathrm{N}$ levels in the upper leaves later into the season. The higher $\mathrm{N}$ content may also represent differences in mineralization of $\mathrm{N}$ between the treatments.

There were also differences in the percentage of $\mathrm{N}$ in the upper leaves that originated from fertilizer (data not shown). At 8 WAP, plants in plots with $336 \mathrm{~kg} \cdot \mathrm{ha}^{-1} \mathrm{~N}$ acquired $59 \%$ observed for upper leaves in our study at 15 WAP were similar to the $36.1 \mathrm{~g} \cdot \mathrm{kg}^{-1}$ for tomato

Table 2. The regression equations predicting the effect of nitrogen rate on tomato plant height and yield. The data are averaged over years except for yield at 15 weeks after planting (WAP) when in 1998, yield was not affected by $\mathrm{N}$ treatment.

\begin{tabular}{lccc}
\hline Time (WAP) & \multicolumn{1}{c}{$\mathrm{Y}^{\mathrm{z}}$} & \multicolumn{1}{c}{ Equation $^{\mathrm{y}}$} & Coefficient of determination \\
\hline 3 & Height & $27.7+0.0233 \mathrm{x}$ & 0.71 \\
5 & Height & $49.3+0.124 \mathrm{x}-0.000225 \mathrm{x}^{2}$ & 0.85 \\
7 & Height & $66.5+0.0952 \mathrm{x}-0.000155 \mathrm{x}^{2}$ & 0.83 \\
12 & Yield & $1.82+0.00364 \mathrm{x}$ & 0.65 \\
15 & Yield & $2.74+0.00461 \mathrm{x}$ & 0.50 \\
\hline
\end{tabular}

${ }^{\mathrm{z}}$ Height is in $\mathrm{cm}$ and yield is in $\mathrm{kg} / \mathrm{plant}$.

y The independent variable $(\mathrm{x})$ is nitrogen at $\mathrm{kg} \cdot \mathrm{ha}^{-1}$.

Table 3. Tomato shoot (foliage and fruit) fresh weight at 12 and 15 weeks after planting (WAP) relative to nitrogen treatments.

\begin{tabular}{|c|c|c|c|c|c|}
\hline \multirow{3}{*}{$\begin{array}{l}\text { Nitrogen } \\
\text { treatment } \\
\left(\mathrm{kg} \cdot \mathrm{ha}^{-1}\right) \mathrm{N}\end{array}$} & & & \multicolumn{3}{|c|}{ Fresh wt/ha } \\
\hline & \multicolumn{2}{|c|}{ Fresh wt/plant } & \multicolumn{2}{|c|}{$12 \mathrm{WAP}^{\mathrm{z}}$} & \multirow[b]{2}{*}{15 WAP } \\
\hline & 12 WAP & 15 WAP & 1998 & 1999 & \\
\hline & $\mathrm{kg} / \mathrm{plant}$ & $\mathrm{Mg} \cdot \mathrm{ha}^{-1}$ & & & \\
\hline $0+$ sawdust $^{\mathrm{y}}$ & $2.18 \mathrm{c}^{\mathrm{x}}$ & $4.10 \mathrm{~b}$ & 24.8 & 17.6 & 79.8 \\
\hline 0 & $2.72 \mathrm{c}$ & $4.21 \mathrm{~b}$ & 31.3 & 21.6 & 81.9 \\
\hline 168 & $3.43 \mathrm{~b}$ & $5.18 \mathrm{a}$ & 36.1 & 30.7 & 101 \\
\hline 336 & $4.17 \mathrm{a}$ & $5.42 \mathrm{a}$ & 39.4 & 41.8 & 106 \\
\hline
\end{tabular}

${ }^{\mathrm{z}}$ At 12 weeks after planting, the year $\times$ rate interaction was significant for shoot fresh weight per hectare.

${ }^{\mathrm{y}}$ Sawdust was applied to the plots at $22 \mathrm{Mg} \cdot \mathrm{ha}^{-1}$ to immobilize nitrogen.

${ }^{x}$ Mean separation in columns using Fisher's protected least significant test, $P=0.05$ 
Table 4. The effect of four fertility treatments on the total nitrogen concentration in tomato tissues $\left(\mathrm{g} \cdot \mathrm{kg}^{-1}\right)$ at 8,12 , or 15 weeks after treatment.

\begin{tabular}{|c|c|c|c|c|c|c|c|c|c|c|}
\hline \multirow{3}{*}{$\begin{array}{l}\text { Nitrogen } \\
\text { treatment } \\
\left(\mathrm{kg} \cdot \mathrm{ha}^{-1}\right) \mathrm{N}\end{array}$} & \multicolumn{4}{|c|}{ Upper leaves } & \multirow{2}{*}{\multicolumn{2}{|c|}{ Lower leaves }} & & & & \\
\hline & \multicolumn{2}{|c|}{$8 \mathrm{WAP}^{2}$} & \multirow[b]{2}{*}{12} & \multirow[b]{2}{*}{15} & & & \multicolumn{2}{|c|}{ Upper stems } & \multicolumn{2}{|c|}{ Lower stems } \\
\hline & 3.2 & 4.2 & & & 12 & 15 & 12 & 15 & 12 & 15 \\
\hline$\overline{0+\text { sawdust }^{\mathrm{y}}}$ & $35.0 \mathrm{~b}^{\mathrm{x}}$ & $41.4 \mathrm{ab}$ & $41.5 \mathrm{a}$ & 36.6 & 23.2 & 18.9 & 19.6 & 13.5 & 12.4 & 11.5 \\
\hline 0 & $38.8 \mathrm{~b}$ & $36.3 \mathrm{~b}$ & $42.3 \mathrm{a}$ & 36.6 & 24.2 & 18.8 & 17.1 & 14.8 & 13.6 & 10.2 \\
\hline 168 & $39.9 \mathrm{~b}$ & $39.9 \mathrm{ab}$ & $35.5 \mathrm{~b}$ & 34.6 & 21.4 & 18.2 & 14.9 & 17.1 & 12.4 & 11.0 \\
\hline 336 & $51.0 \mathrm{a}$ & $45.3 \mathrm{a}$ & $35.8 \mathrm{~b}$ & 36.8 & 20.8 & 19.4 & 16.0 & 15.0 & 12.9 & 12.2 \\
\hline
\end{tabular}

${ }^{2}$ The population $\times$ rate interaction affected $\mathrm{N}$ concentration of the upper leaves, therefore the total nitrogen content of leaves in the 3.2 and 4.2 plants $/ \mathrm{m}^{2}$ are shown separately.

${ }^{y}$ Sawdust was applied to the plots at $22 \mathrm{Mg} \cdot \mathrm{ha}^{-1}$ to immobilize nitrogen.

${ }^{x}$ Mean separation within column using Fisher's protected least significant test, $P=0.05$. Means in columns without letters were not significantly different.

of their total $\mathrm{N}$ from applied $\mathrm{N}$, compared to $39 \%$ in plots treated with $168 \mathrm{~kg} \cdot \mathrm{ha}^{-1} \mathrm{~N}$, but by 10 WAP, these percentages were only $23 \%$ and $11 \%$, respectively. This could be due to $\mathrm{N}$ fertilizer loss in the soil, increased available $\mathrm{N}$ due to mineralization, and remobilization of $\mathrm{N}$ to other plant parts such as fruit, and a "dilution effect" due to growth.

This study does eliminate some production strategies that could be used for optimizing tomato growth and yield while increasing the sustainability of the cropping system. Both the
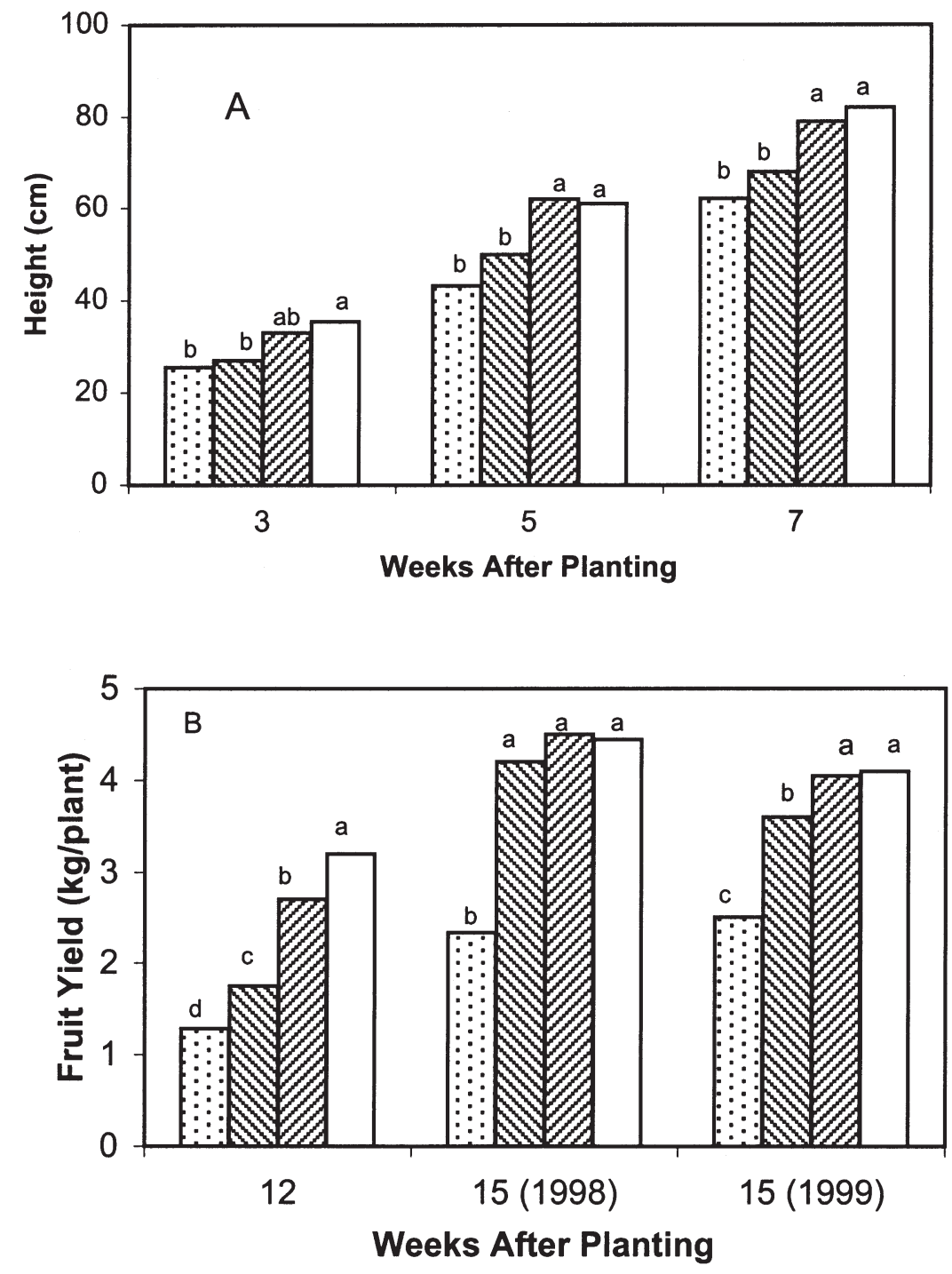

Fig. 3. (A) Tomato plant height and (B) yield in response to nitrogen treatment. Tomato height was measured at 3,5, and 7 weeks after planting (WAP) in $0 \mathrm{~N}+22 \mathrm{Mg} \cdot \mathrm{ha}^{-1}$ sawdust (dots), $0 \mathrm{~N}$ (downward hatched), $168 \mathrm{~kg} \cdot \mathrm{ha}^{-1} \mathrm{~N}$ (upward hatched) and $336 \mathrm{~kg} \cdot \mathrm{ha}^{-1} \mathrm{~N}$ (open). Fruit yield was measured at 12 (averaged over 1998 and 1999) and 15 (1998 and 1999 separately) the bar hatching is the same as for height. Bars within date with the same letter are not significantly different using Fisher's protected least significant test, $P=0.05$. greenhouse hydroponic and the field studies indicate that tomato growth is improved with high levels of $\mathrm{N}$ and indicates that reducing $\mathrm{N}$ would reduce tomato growth. With higher $\mathrm{N}$ concentrations, tomato plants grew more rapidly and were larger, which would make them able to support greater fruit loads. Thus, the best fertilizer strategy is to apply adequate $\mathrm{N}$ to allow optimum tomato growth. The problem with this strategy is that the optimum $\mathrm{N}$ rate for tomato varies even on the same soil type, depending on the environmental conditions and time of measurement. Because of this variation, there will be years when $\mathrm{N}$ applications will exceed the needs of the tomatoes, and result in environmental contamination.

Placing $\mathrm{N}$ fertilizer in the transplant row where it is readily available to tomato or applying high rates of $\mathrm{N}$ to greenhouse seedlings might be ways to manipulate fertilization to increase tomato growth and yield while minimizing $\mathrm{N}$ loss into the environment. Wyatt et al. (2001) reported that the highest tomato yields were from banding potassium nitrate over the row before transplanting. Other researchers have found that tomato seedlings grown with high $\mathrm{N}$ levels had enhanced growth and survival after transplanting (Liptay and Nicholls, 1993; Melton and Dufault, 1991). Further research is needed to test these strategies.

\section{Literature Cited}

Asher, C.J. 1978. Natural and synthetic culture media for spermatophytes, p. 575-609. In: M. Rechcigl, Jr. (ed.). Culture media for microorganisms and plants. Section G: Diets, culture media, food supplements. Vol. III. CRC Press, Cleveland, Ohio.

Croster, M.P. and J.B. Masiunas. 1998. The effect of weed-free period and nitrogen on eastern black nightshade competition with English pea. HortScience 33:88-92.

Di Tomaso, J.M. 1995. Approaches for improving crop competitiveness through the manipulation of fertilization strategies. Weed Sci. 43:491-497.

Dufault, R.J., D.R. Decoteau, J.T. Garrett, K.D. Batal, D. Granberry, J.M. Davis, G. Hoyt, and D. Sanders. 2000. Influence of cover crops and inorganic nitrogen fertilization on tomato and snap bean production and soil nitrate distribution. J. Veg. Crop Prod. 6(2):13-25.

Dyck, E. and M. Liebman. 1994. Soil fertility as a factor in weed control: The effect of crimson clover residue, synthetic nitrogen fertilizer, and their interaction on emergence and early growth of lambsquarters and sweet corn. Plant Soil 167:227-237.

Garton, R.W. and I.E. Widders. 1990. Nitrogen and 
phosphorus preconditioning of small-plug seedlings influence processing tomato productivity. HortScience 25:655-657.

Gonzalez Pounce, R., C. Zancada, M. Verdugo, and L. Salas. 1996. Plant height as a factor in competition between black nightshade and two horticultural crops (tomato and pepper). J. Hort. Sci. 71:453-460.

Gonzalez Pounce, R. and M.L. Salas. 1999. Differential utilization of nitrates by solanaceous species, crops (tomato and pepper) and weeds (black nightshade and thorn apple). J. Hort. Sci. Biotechnol. 74:254-258.

Hoyt, G.D., D.W. Monks, and T.J. Monaco. 1994. Conservation tillage for vegetable production. HortTechnology 4:129-135.

Hauck, R.D., J.J. Meisinger, and R.L. Mulvaney. 1994. Practical considerations in the use of nitrogen tracers in agricultural and environmental research, p. 907-950. In: R.W. Weaver (ed.). Methods of soil analysis. Part 2. SSSA Book Ser. 5. SSSA, Madison, Wisc.

Liptay, A. and S. Nicholls. 1993. Nitrogen supply during greenhouse transplant production affects subsequent tomato root growth in the field. J. Amer. Soc. Hort. Sci. 118:339-342.

McGiffen, M.E., Jr. and J.B. Masiunas. 1992a. Prediction of black and eastern black nightshade (Solanum nigrum and S. ptycanthum) growth using degree-days. Weed Sci. 40:86-89.

McGiffen, M.E., Jr., J.B. Masiunas, and J.D. Hesketh. 1992b. Competition for light between tomatoes and nightshades (Solanum nigrum or S. ptycanthum). Weed Sci. 40:220-226.
Melton, R.R. and R.J. Dufault. 1991. Nitrogen, phosphorus, and potassium fertility regimes affect tomato transplant growth. HortScience 26:141-142.

Mortley, D.G., C.B. Smith, and K.T. Demchak. 1991. Fertilizer placement affects growth, fruit yield, and elemental concentrations and contents of tomato plants. J. Amer. Soc. Hort. Sci. 116: 659-662.

Moore, S.H. 1991 Uniformity of plant spacing effect on soybean population parameters. Crop Sci. 31:1049-1051.

Perez,F.G.M. and J.B. Masiunas. 1990. Eastern black nightshade (Solanum ptycanthum) interference in processing tomato (Lycopersiconesculentum). Weed Sci. 38:385-388.

Qasem, J.R. 1992. Nutrient accumulation by weeds and their associated vegetable crops. J. Hort. Sci. 67:189-195.

Resh, H.M. 1995. Hydroponic Food Production. Woodbridge Press, Santa Barbara, Calif.

Sainju, U.M., B.P. Singh, and S. Rahman. 2000 Tomato root growth is influenced by tillage, cover cropping, and nitrogen fertilization. HortScience 35:78-82.

Sanchez, C.A. and T.A. Doerge. 1999. Using nutrient uptake patterns to develop efficient nitrogen management strategies for vegetables. HortTechnology 9:601-606.

Smith, C.B., K.T. Demchak, P.A. Ferretti, and M.D. Orzolek. 1992. Plant density as related to fertilizer needs for processing and fresh market tomatoes. Commun. Soil Sci. Plant Anal. 23: 1439-1449.
Stevens, W.B., R L. Mulvaney, S.A. Khan, and R.G. Hoeft. 2000. Improved diffusion methods for nitrogen and ${ }^{15}$ Nitrogen analysis of Kjeldahl digests. J. AOAC Intl. 83:1039-1046.

Univ. of Illinois Cooperative Extension Service [UICES]. 2001. Midwest vegetable production guide for commercial growers, p. 137-148. Univ. of Illinois Ext. Circ. C1373.

U.S. Dept. of Agriculture (USDA)-National Agricultural Statistics Service. 2001. Agricultural statistics. Section 4: Statistics of vegetables and melons. U.S. Govt. Printing Office, Washington, D.C.

Wahle,E.A. 2001. Competition for nitrogen between eastern black nightshade and fresh market tomatoes. PhD Thesis, Univ. of Illinois, Urbana,

Wahle, E.A. and J.B. Masiunas. 2003a. Comparison of nitrogen use by two population densities of eastern black nightshade. Weed Sci. 51: 394-401.

Wahle, E. A. and J. B. Masiunas. 2003b. Competition for nitrogen between eastern black nightshade and fresh market tomato. Weed Sci. (In press.)

Wilcox, G.E. 1993. Tomato, p. 137-141. In: W.F. Bennett(ed.). Nutrient deficiencies and toxicities in crop plants. APS Press, St. Paul, Minn.

Wyatt, J.E., D.D. Tyler, C.H Canaday, and D.D. Howard. 2001. Tillage and fertilizer placement effects on staked tomatoes were inconsistent. HortTechnology 11:575-579.

Yaffa, S., U.M. Sainju, B.P. Singh, and K.C. Reddy. 2000. Fresh market tomato yield and soil nitrogen as affected by tillage, cover cropping, and nitrogen fertilization. HortScience 37:1258-1262. 